\title{
Snowflake
}

\section{Caleb Emmons}

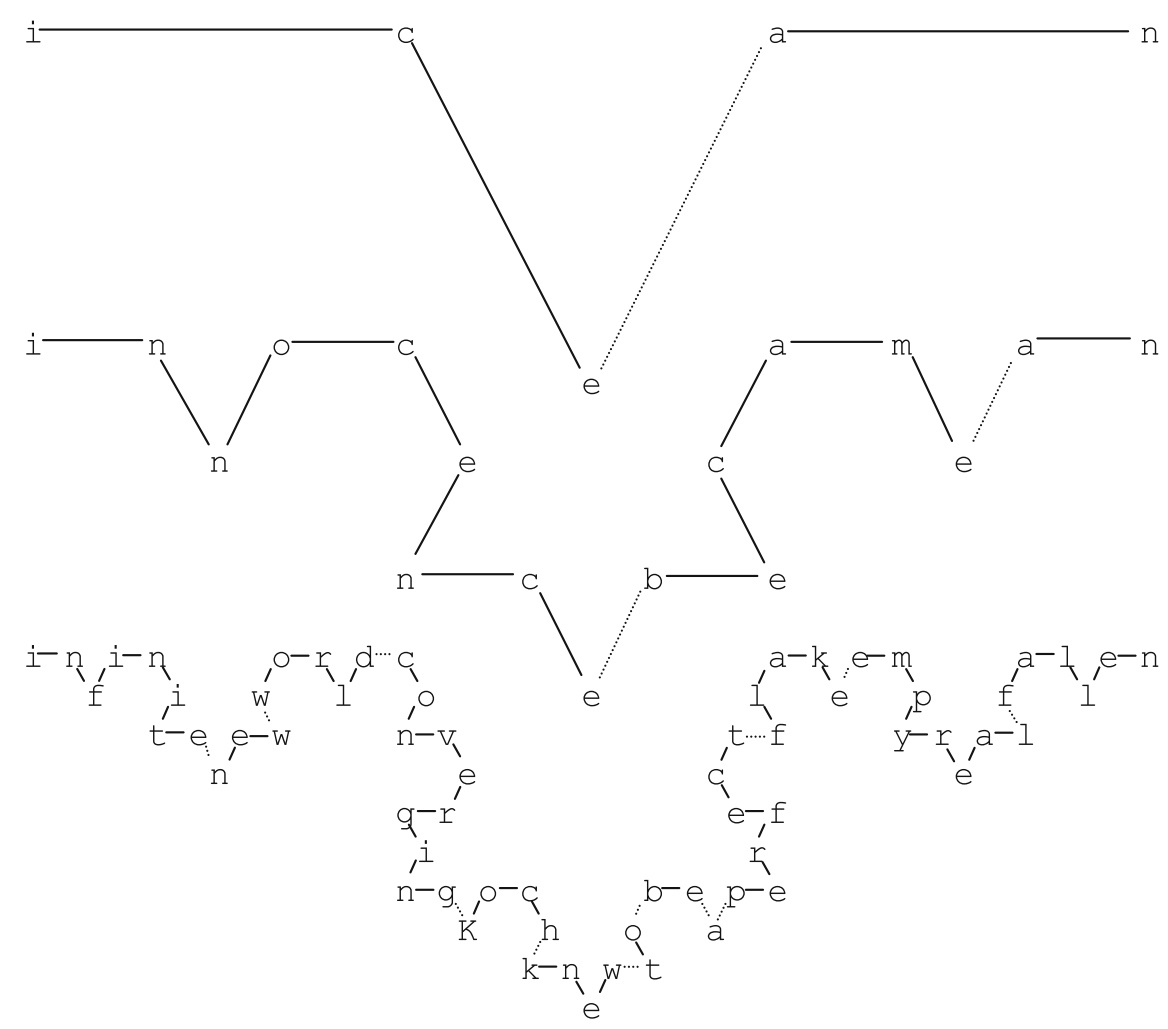

Department of Mathematics and Computer 